\title{
The assessment of infection control in dental practices in the municipality of São Paulo
}

\begin{abstract}
Objective: The goal of this study was to evaluate the infection control measures actually implemented by dental surgeons during dental practice, as patients and professionals are exposed to high biological risk in dental care environments. Method: 614 questionnaires (90.69\%) were answered by professionals registered in updating or in post-graduate courses in the Municipality of São Paulo. Results: Out of surveyed professionals $30.62 \%$ admitted that surface protection barriers were not used, whereas $34.17 \%$ were using non ideal or outdated pre-disinfection practices. The autoclave was used by $69.38 \%$ of participants, although $33.80 \%$ were not monitoring control of the sterilization cycles. Chemical and biological indicators were not used simultaneously by $83.21 \%$ of respondents and were not employed on a daily or weekly basis by at least $81.75 \%$. Dubious methods of sterilization were cited by $44.77 \%$. Occupational accidents caused by cutting and piercing objects were reported by $47.88 \%$; however, the biologic risk was underestimated by $74.15 \%$ of the professionals who suffered the accidents. Irritant solutions were used as an antiseptic agent by $18.55 \%$. Conclusions: Infection control measures reported by dental surgeons during their practices are deficient. It is necessary to educate, raise awareness of professionals, and promote constant updating courses on procedures which aim at improving safety of dental care.
\end{abstract}

Keywords: infection control; sterilization; occupational accidents; dentistry.

[Braz J Infect Dis 2011;15(1):45-51] @Elsevier Editora Ltda.

\section{INTRODUCTION}

Biosafety is a concern in all health sector services. Confronted with a high biological risk both for patients and professionals in dental care and due to the constant development of new technologies, information, equipment, material and behavioral attitudes in this area, ${ }^{1-3}$ Health Organizations such as the Center for Disease Control (CDC), the American Dental Association (ADA), the National Sanitary Department (ANVISA) and the Ministry of Health $(\mathrm{MOH})$ among others, have developed guidelines to prevent, minimize or eliminate any threat to life or health during treatment. These guidelines, given the peculiarities of dentistry activity, should be followed by the professional and his team before, during, and after care for all patients and for all types of treatment. This includes all instruments and equipment used, regardless of the confirmed or presumed diagnosis, being infectious or not. ${ }^{4-5}$
The environment in dentistry practices and clinics is far from ideal. ${ }^{6}$ However, the adoption of infection control measures is an effective way to reduce occupational risk and the transmission of pathogens, mainly through saliva, blood, air or water. These measures essentially include (I) cleaning, disinfection and sterilization; (II) the use of personal equipment protection; (III) immunization; (IV) prevention and correct handling in occupational accidents which involve exposure to blood and bodily fluids; and (V) antisepsis. ${ }^{7-9}$

Still, written reports have shown that the most common biosafety problem is not related to available technology to eliminate or minimize risks, but rather the behavior of professionals. ${ }^{1-3 ; 10}$

A well-informed and alert professional is capable of performing his procedures without putting himself at risk or the health of his patients. Consequently, the goal of this study was to assess current infection control measures adopted by dental surgeons during their practice.
Authors

Jacqueline Kimiko

Matsuda $^{1}$

Renato Satovschi

Grinbaum ${ }^{2}$

Harry Davidowicz ${ }^{3}$

${ }^{1} \mathrm{MD}, \mathrm{MSc}$, Instituto de Assistência Médica ao Servidor Público Estadual IAMSPE

${ }^{2} \mathrm{MD}, \mathrm{PhD}$, Hospital do

Servidor Público Estadual

"Francisco Morato de

Oliveira" (HSPE-FMO),

São Paulo, SP

${ }^{3} \mathrm{PhD}$, Ful Professor of

Endodonty - Universidade

Paulista (UNIP),

São Paulo, SP
Submitted on: 06/09/2010 Approved on: 07/27/2010

Correspondence to: Jacqueline Kimiko Matsuda

Instituto de Assistência Médica ao Servidor

Público Estadual

Pós Graduação em

Ciências da Saúde

Av. Ibirapuera, 981 -

$2^{\circ}$ andar - Vila Clementino

São Paulo - SP

04029-000

Phone: (5511) 5088-8268 5088-8657

dra.jkm@hotmail.com

We declare no conflict of interest. 


\section{METHOD}

Between March $1^{\text {st }}$ and April $30^{\text {th }} 2009$, self-administered structured questionnaires were offered to 677 professionals registered in updating or post-graduation courses in the Municipality of São Paulo, regardless of sex, age, field of expertise or graduation period.

Professionals from different specialties from the following institutions were included: Abitep; Fapes; Unip; Fousp; Uniban; Cetao; APCD Ipiranga and Funorte Tatuapé. The criterion for the selection of these institutions was the easiness of access and gathering data.

Questionnaires with less than $70 \%$ of completed answers were excluded. Therefore, the sample consisted of $614(90.69 \%)$ participants, which corresponds to $26.24 \%$ of the total sample enrolled $(\mathrm{N}=2.340)$ in specialization courses ongoing in the State of São Paulo, according to the Federal Dentistry Council (site).

Questionnaires were handed out to the selected professionals with no prior contact between the researcher and professionals. A pilot test was conducted with 10 professionals to assess the validity of the research instrument, followed by obtaining signed consent from study participants.

The information gathered in the questionnaires dealt with the following areas: (I) general information of participants: sex, age, period since graduation, post graduation, clinical procedures, and patient attendance systems; (II) infection control in dental clinics characterized by: a) use of surface protective barriers, b) usages of disinfectants, c) methods of sterilization, both physical and chemical, d) monitoring of sterilization processes in autoclave through chemical and biological indicators; (III) occupational accidents and immunization defined by: a) cases of exposure to biological materials, b) products used on injured areas, c) vaccinations against immune-preventive illnesses.

The research project was approved by the Committee for Ethical Research of IAMSPE (protocol no 067/07).

\section{RESULTS}

Table 1 shows demographic and educational information of the of the 614 dental surgeons surveyed; $70.36 \%$ were female, the mean age was 34 years, and $46.58 \%$ had been graduated for 10 years or more. The majority $(54.72 \%)$ had postgraduate training, with specializations mainly on endodontic (18.90\%) and dental implant $(12.93 \%)$. A high percentage $(87.30 \%)$ performs surgical procedures, $46.34 \%$ of professionals assisted patients from the public sector and both private and health insured patients; $44.67 \%$ provide care to private patients only, $6.66 \%$ worked at the public sector, and $2.33 \%$ with health plans.
Table 1. Demographic and educational information of the 614 dental surgeons surveyed

\begin{tabular}{|c|c|c|}
\hline $\begin{array}{l}\text { History } \\
\quad \text { frequency }(\mathrm{N})\end{array}$ & $\begin{array}{l}\text { Absolute } \\
\text { requency (\%) }\end{array}$ & Relative \\
\hline \multicolumn{3}{|l|}{ Gender } \\
\hline Female & 432 & 70.36 \\
\hline Male & 182 & 29.64 \\
\hline \multicolumn{3}{|l|}{ Age (years) } \\
\hline 21 to 30 & 210 & 34.20 \\
\hline 31 to 40 & 246 & 40.06 \\
\hline 41 to 50 & 108 & 17.59 \\
\hline 51 to 60 & 34 & 5.54 \\
\hline Over 60 & 16 & 2.61 \\
\hline \multicolumn{3}{|l|}{$\begin{array}{l}\text { Time period since } \\
\text { Graduation (years) }\end{array}$} \\
\hline 0 to 4 & 142 & 23.13 \\
\hline 5 to 10 & 186 & 30.29 \\
\hline Over 10 & 286 & 46.58 \\
\hline Post Graduation & 336 & 54.72 \\
\hline \multicolumn{3}{|l|}{ Specialty } \\
\hline Endodontics & 76 & 18.90 \\
\hline Implantology & 52 & 12.93 \\
\hline Prosthodontics & 46 & 11.44 \\
\hline Pediatric Dentistry & 40 & 9.95 \\
\hline Periodontics & 34 & 8.46 \\
\hline Dentistry & 32 & 7.96 \\
\hline СТВМF & 26 & 6.47 \\
\hline Others & 96 & 23.88 \\
\hline \multicolumn{3}{|l|}{ Perform procedures } \\
\hline Surgical & 44 & 7.17 \\
\hline Non surgical & 78 & 12.70 \\
\hline $\begin{array}{l}\text { Surgical and } \\
\text { non surgical }\end{array}$ & 492 & 80.13 \\
\hline \multicolumn{3}{|l|}{ Patient attendance } \\
\hline Private & 268 & 44.67 \\
\hline Public Service & 40 & 6.66 \\
\hline Health/Dental Insuran & nce 14 & 2.33 \\
\hline $\begin{array}{l}\text { More than } \\
\text { one attendance }\end{array}$ & 278 & 46.34 \\
\hline & \multicolumn{2}{|c|}{ Average (Minimum-Maximum) } \\
\hline Age (years) & 34 & $(21-72)$ \\
\hline $\begin{array}{l}\text { Time period since } \\
\text { Graduation (years) }\end{array}$ & 10 & $(01-46)$ \\
\hline
\end{tabular}

*Updated and Postgraduation courses: Abitep; Fapes; Unip; Fousp; Uniban; Cetao; Apcd; and Funorte. 
Table 2 shows the infection control methods used by the surveyed professionals in dental clinics. It was observed that $69.38 \%$ used protection barriers on surfaces. Almost all of them (95.11\%) reported pre-disinfection of tools used in the surgeries. However, a closer analysis of the results indicated that $65.83 \%$ of dental

Table 2. Absolute and relative frequency referring to the methods of infection control in dental clinic of 614 dental surgeons surveyed from 03/01/09 to 04/30/09 and enrolled in updating courses or postgraduation in the Municipality of São Paulo

\begin{tabular}{lcc}
\hline $\begin{array}{l}\text { Utilized methods } \\
\text { for infection control }\end{array}$ & $\begin{array}{c}\text { Absolute } \\
\text { frequency (N) }\end{array}$ & $\begin{array}{c}\text { Relative } \\
\text { frequency (\%) }\end{array}$ \\
\hline $\begin{array}{l}\text { Barrier protection of surfaces } \\
\text { PVC film / coating latex }\end{array}$ & 426 & 69.38 \\
\hline Pre-disinfection of objects & 584 & 95.11 \\
\hline Pre-disinfection practice & & \\
$\quad$ Soap and water/detergent & 212 & 22.22 \\
Enzymatic detergent & 198 & 20.75 \\
Glutaraldehyde at 2\% & 188 & 19.71 \\
Ultrasonic washer & 102 & 10.69 \\
Alcohol & 100 & 10.48 \\
Dencrusting solution & 100 & 10.48 \\
Sodium hypochlorite & 32 & 3.35 \\
Thermo-disinfectant washer & 16 & 1.68 \\
Formaldehyde & 6 & 0.63 \\
\hline Sterilization methods & & \\
Oven & 66 & 10.75 \\
Autoclave & 426 & 69.38 \\
Oven and Autoclave & 122 & 19.87 \\
\hline
\end{tabular}

surgeons showed a misunderstanding between manual hygiene practices $(53.45 \%)$ or automated hygiene practices $(12.37 \%)$, with pre-disinfection $(34.17 \%)$. The solution most commonly used for pre-disinfection was glutaraldehyde at 2\% (19.71\%). The autoclave was adopted by $69.38 \%$ of participants.

In Table 3, the usage, frequency and the types of indicators of sterilization are presented. It was observed that $66.7 \%$ of professionals used monitoring indicators for the autoclave. The majority referred a frequency greater than 30 days $(34.31 \%)$. Biological indicator $(47.44 \%)$ was the most frequent, followed by chemical indicator $(35.77 \%)$ and a combination of the two types (16.79\%).

Table 4 shows that not only the autoclave (55.23\%) but also the dry-heat sterilizer (8.75\%), chemical solutions (19.32\%) and alcohol (16.66\%) were used as a means of "sterilization" for any type of dentistry equipment and tools.

Table 3. Number and percentage of usage, frequency and the types of indicators of sterilization used in autoclave of 614 dental surgeons surveyed

\begin{tabular}{lcc}
\hline Autoclave & $\begin{array}{c}\text { Absolute } \\
\text { frequency (N) }\end{array}$ & $\begin{array}{c}\text { Relative } \\
\text { frequency (\%) }\end{array}$ \\
\hline Reports to use indicator & 282 & 66.20 \\
\hline $\begin{array}{l}\text { Frequency } \\
\quad \text { Daily }\end{array}$ & 10 & 3.65 \\
$\quad$ Weekly & 40 & 14.60 \\
$\quad$ Every 2 weeks & 40 & 14.60 \\
$\quad$ Monthly & 90 & 32.85 \\
$\quad$ Less than once a month & 94 & 34.31 \\
\hline Indicator type & & \\
$\quad$ Biological & 130 & 47.44 \\
$\quad$ Chemical & 98 & 35.77 \\
Biological and Chemical & 46 & 16.79 \\
\hline
\end{tabular}

Table 4. "Sterilization" methods employed for some dental materials and instruments used by 614 dental surgeons

\begin{tabular}{|c|c|c|c|c|c|}
\hline $\begin{array}{l}\text { Material and } \\
\text { instruments }\end{array}$ & $\begin{array}{c}\text { Autoclave } \\
\text { N (\%) }\end{array}$ & $\begin{array}{l}\text { Oven } \\
\text { N (\%) }\end{array}$ & $\begin{array}{c}\text { Chemical } \\
\text { solutions N (\%) }\end{array}$ & $\begin{array}{c}\text { Alcohol 70\% } \\
\text { N (\%) }\end{array}$ & $\begin{array}{l}\text { Total } \\
\mathrm{N}\end{array}$ \\
\hline Orthodontic pliers & $282(56.17)$ & $38(7.57)$ & $48(9.56)$ & $134(26.69)$ & 502 \\
\hline Diamond point & $364(52.15)$ & $82(11.75)$ & 224 (32.09) & $28(4.01)$ & 698 \\
\hline Turbine handpiece & $278(39.26)$ & $14(1.98)$ & $106(14.97)$ & $310(43.78)$ & 708 \\
\hline Almagam plugger & $484(77.07)$ & $100(15.92)$ & $30(4.78)$ & $14(2.23)$ & 628 \\
\hline Dental mirror & $518(78.48)$ & $102(15,45)$ & $32(4.85)$ & $8(1.21)$ & 660 \\
\hline Surgical instruments & $524(80.37)$ & $94(14.42)$ & $32(4.91)$ & $2(0.31)$ & 652 \\
\hline Endodontic files & $482(77.74)$ & $88(14.19)$ & $48(7.74)$ & $2(0.32)$ & 620 \\
\hline Impression tray & $430(66.36)$ & $86(13.27)$ & $76(11.73)$ & $56(8.64)$ & 648 \\
\hline Glass plates & 252 (36.95) & $28(4.10)$ & $140(20.53)$ & $262(38,42)$ & 682 \\
\hline Amalgam carrier & $388(65.10)$ & $70(11.74)$ & $62(10.40)$ & $76(12.75)$ & 596 \\
\hline Film holder & $158(24.31)$ & $4(0.61)$ & $332(51.08)$ & $156(24.00)$ & 650 \\
\hline Dappen pot & $202(31.76)$ & $14(2.20)$ & $158(24.84)$ & 262 (41.19) & 636 \\
\hline Prophylaxis cups & $220(35.71)$ & $6(0.97)$ & $318(51.62)$ & 72 (11.69) & 616 \\
\hline Total & $4,582(55.23)$ & $726(8.75)$ & $1,606(19.36)$ & $1,382(16.66)$ & 8,296 \\
\hline
\end{tabular}


Occupational hazards as well as preventive and prophylactic actions taken in case of such occurance are summarized in Table 5. Occupational accidents with cutting and piercing objects potentially contaminated $47.88 \%$ of professionals. Among the victims, only $25.85 \%$ sought specialized medical assistance. Of these, $42.10 \%$ received antiretroviral drugs and $5.26 \%$ vaccination for hepatitis B. The majority $(92.62 \%)$ already had received the full course of hepatitis B immunization. However, only $65.85 \%$ had serologic ascertainment of the vaccine effectiveness and out of those $92.82 \%$ were immune. The vast majority of dental surgeons (95.76\%) prioritized usage of some type of product to clean areas injured by sharp puncturing objects, potentially contaminated. Soap and water (52.04\%) was the product most frequently mentioned.

Table 5. Occupational hazards, preventive measures and prophylactics adopted for biological exposure of 614 dental surgeons surveyed

\begin{tabular}{|c|c|c|}
\hline $\begin{array}{l}\text { Occupational hazard / } \\
\text { measures }\end{array}$ & $\begin{array}{c}\text { Absolute } \\
\text { frequency (N) }\end{array}$ & $\begin{array}{c}\text { Relative } \\
\text { frequency (\%) }\end{array}$ \\
\hline \multicolumn{3}{|l|}{ Occupational hazard } \\
\hline $\begin{array}{l}\text { Accident with cutting } \\
\text { and piercing objects }\end{array}$ & 294 & 47.88 \\
\hline $\begin{array}{l}\text { Patients that sought } \\
\text { specialized assistance }\end{array}$ & 76 & 25.85 \\
\hline Needed antiretroviral & 32 & 42.10 \\
\hline Needed anti-HBV vaccine & 4 & 5.26 \\
\hline \multicolumn{3}{|l|}{ Preventive measure } \\
\hline Anti-HBV vaccine & 596 & 97.07 \\
\hline Complete dosage & 552 & 92.62 \\
\hline Serologic test & 362 & 65.58 \\
\hline Immunized & 336 & 92.82 \\
\hline \multicolumn{3}{|l|}{ Prophylactic measures } \\
\hline $\begin{array}{l}\text { Topic product } \\
\text { pos-exposure }\end{array}$ & 588 & 95.76 \\
\hline \multicolumn{3}{|l|}{ Types of products utilized } \\
\hline Soap and water & 460 & 52.04 \\
\hline Chlorhexidine & 140 & 15.84 \\
\hline Alcohol & 102 & 11.54 \\
\hline Hypochlorite & 90 & 10.18 \\
\hline Hydrogen peroxide & 74 & 8.37 \\
\hline Povidone iodine & 18 & 2.04 \\
\hline
\end{tabular}

\section{DISCUSSION}

Dentistry is a profession that involves constant risk of exposure to various environmental and human infectious agents, transmitted through blood, oral and oropharyngeal secretions, air and water. ${ }^{11}$ Contamination can affect staff, patients and even members of their family. Occupational hazards involving blood and other organic fluids account for the most frequent exposure resulting in a higher risk of contracting diseases such as HIV, hepatitis B and C, meningococcal disease, mononucleosis, herpes, among others. ${ }^{12,13}$ In the light of these facts, we highlight some actions that ought to be adhered to in order to reduce the risks in the practice of dentistry: (I) cleaning, disinfection and sterilization; (II) the usage of barriers and protective equipment; (III) immunization; (IV) prevention and handling of occupational hazards; (V) antisepsis. ${ }^{14,15}$

However, the literature shows that these actions are not always seriously implemented by professionals despite of their relevance and the large number of publications related to this subject. ${ }^{1-3,10}$ Towards that end, to obtain effective control of contamination in dentistry environments it is necessary to further educate on health and raise awareness of professionals to the risks of exposure, as well as to the prevention of transmitted pathogens, through accurate and updated information.

Some of the data obtained in our study, conducted with participants of upgrading and postgraduate courses, deserve special consideration, as it reveals the flaws and needs in biosafety dentistry.

The utilization of protection barriers aims at minimizing the contamination of surfaces and equipment by microorganisms existing in the environment or on the hands of the professional. ${ }^{16} \mathrm{~A}$ study carried out by Bulgarelli et al. ${ }^{17}$ emphasizes that the use of disposable barriers for each patient reduces bacterial contamination by $70 \%$. Despite easy availability of this resource, $30.62 \%$ of participants reported not to make use of it which may translate the indifference to preventive measures and cross contamination control. This finding underscores the need for adjustment and change in habits.

Prior disinfection is characterized by soaking the instruments contaminated by organic material in chemical disinfectant solutions, before cleaning, in order to reduce risks of pathogen exposures to the professional. However, research shows that this practice is not based on scientific evidence, as the organic material can interfere in the antimicrobial activity of disinfectants. ${ }^{18-20}$ As such, prior disinfection admitted by $34.17 \%$ of those surveyed is no longer recommended, as besides giving a false sense of safety when handling objects, there is no evidence that it reduces hazard risks. Persistence in this 
practice is probably justified by the absence of pertinent information.

Asymptomatic patients, whether carriers of infectious diseases or not, are assisted by dental surgeons every day, making sterilization processes and validation of paramount importance. In our research, autoclave (moist-heat by steam), oven (dry-heat sterilizer), chemical solutions and alcohol were analyzed as methods of "sterilization".

Autoclave is considered the preferred method due to its safety, quickness and its lethal effect of pressurized steam on all microorganisms. ${ }^{5,7,18}$ Nonetheless, recent studies have shown that $12 \%$ to $33 \%$ of these devices present defects ${ }^{21}$ easily detectable with periodical monitoring of the cycles and the simultaneous use of different sterilization indicators. ${ }^{22}$ Findings by Monarca et al. ${ }^{23}$ and by Corrêa ${ }^{24}$ show respectively, $68.60 \%$ and $72.55 \%$ of autoclave users with $27.40 \%$ and $26.95 \%$ referring no use of indicators. Similar results were observed in our study, where $69.38 \%$ of participants used autoclave and $33.80 \%$ of these did not use indicators. Daily use or at least weekly us of indicators, as well as the combined use of different indicators, were ignored by $81.75 \%$ and $83.21 \%$, respectively. The free use of material and/or instruments with no certification of correct sterilization is a large concern in respect to biosafety.

The literature describes the oven as a secure method for sterilization, but it is less appropriate than the autoclave, mainly as it permits the interruption of process, by the heterogeneity of penetration and heat distribution inside the chamber, by the absence of a precision thermostat to effectively control temperature and because it requires prolonged exposure to high temperatures. ${ }^{21}$ Due to these issues, sterilization in a dry-heat sterilizer which seemed to be the practice of approximately $10 \%$ of the participants in our research is currently recommended just for metal blades, points, cutting or drill instruments sensitive to oxidization by steam..$^{25}$

Chemical solutions are also referred to as sterilizers provided their concentration and length of exposure. ${ }^{7}$ They are also considered toxic and irritant, with limited action and effectiveness. Therefore they are restricted to thermo sensitive material and are used as a last resource for sterilization, on scientific grounds. ${ }^{18}$ Although alcohol at $70 \%$ eliminates the majority of microorganisms found on equipment and surfaces, it is not sporicidal and is just an intermediate-level disinfectant agent. ${ }^{19}$ In the light of this and the data obtained in Table 4, we emphasize that choice of using the dry-heat sterilizer $(8.75 \%)$ and chemical germicides solutions (19.36\%) to sterilize equipment should be discouraged and have its effectiveness evaluated through strict parameters. Alcohol $(16.66 \%)$ as a method of sterilization is totally unacceptable. Therefore, ineffective methods (44.77\%) with subsequent transmission of infection and risking patients and professionals' health must be substituted.

Many dentistry instruments are sharp and piercing and can easily cause lesions when handled. This type of accident, mainly with exposure to blood or bodily fluids should be treated as urgency, as the fastest the prophylaxis is initiated, the better the prognosis. ${ }^{26}$ In our data we identified $47.88 \%$ of dental surgeons who reported accidents with potentially contaminated material. However, biological risk was overlooked in $74.15 \%$ of these incidents, since only $25.85 \%$ sought specialized medical assistance and of these, $42.10 \%$ were instructed to begin antiretroviral chemoprophylaxis and 5.26\% received vaccination against hepatitis $\mathrm{B}$. Our results also confirm that $92.62 \%$ of dental surgeons had full vaccination course for anti-HBV, although $34.42 \%$ of them have not subsequently ascertained serological response. Such neglectful behavior was also detected by Gordon et al..$^{27}$ and Reis ${ }^{28}$ who concluded in their studies that despite the frequent occurrence of incidents involving cutting and piercing objects, the risks of infection are underestimated by the professionals. A greater number of accidents, however, with fewer people seeking specialized assistance and serological monitoring were observed in other studies, such as reported by Veronesi et al. ${ }^{29}$ in Italy, where they found $73 \%$ of accidents, with $28.2 \%$ not verifying seroconversion, and a maximum of $44.94 \%$ of awareness of risk of infection. As in the study by Khadar, ${ }^{30}$ in Jordan, there was $66.50 \%$ of accidents, with only $22.10 \%$ reported lesions. Based on this, it is crucia to understand that implementation of available preventive measures and effective prophylactics interventions should be based on individual analysis of the risk of infection.

According to Silva et al., ${ }^{31}$ exposure to biological materials represents the principal occupational risk to health professionals who deal with patients directly. The nature of accidents evaluated in his study indicated that the majority of them were percutaneous (92.4\%), affecting mainly fingers $(84.6 \%)$ and involving blood as biological material $(86.3 \%)$. In a study by Lima et al., ${ }^{32}$ an anesthetic needle $(19.4 \%)$ and an exploratory probe No $^{\circ}$ $5(16.4 \%)$ were the most frequently mentioned instruments. Appropriate care of the injured and exposed area is essential, highlighting: do not squeeze or enlarge in any way the lesion and cleanse the injured $\operatorname{skin}^{26}$ with soap and water $(52.04 \%)$, chlorhexidine $(15.84 \%)$ or antiseptic liquids such as povidone-iodine $10 \%$ PVPI $(2.04 \%)$ or alcohol $70 \%(11.54 \%)$. The use of irritant solutions such as hypochlorite $(10.18 \%)$ and hydrogen peroxide $(8.37 \%)$, seen in our study, are not recommended as an antiseptic as they worsen the wound 
and facilitate infection. ${ }^{28}$ This way, professionals should be fully aware and adhere to information of the correct guidelines in case on an accident.

\section{CONCLUSION}

Taking into account the initial proposal and the results obtained, we can conclude that infection control actions implemented by dental surgeons in this study in their dental practice are far from ideal. The critical points observed were: absence of protective barriers on surfaces; use of non recommended methods of disinfection; use of ineffective methods of sterilization; lack of monitoring of autoclave sterilization cycles; failure to use indicators; negligent behavior in post occupational accidents; and use of irritant antiseptic solutions. It is necessary to educate, raise awareness of professionals, and promote constant updating courses on procedures aiming at improving safety in the dentistry practice.

\section{REFERENCES}

1. Garbin AJI, Garbin CAS, Arcieri RM et al. Biosecurity in public and private office. J Appl Oral Sci. 2005 Jun; 13(2):163-6.

2. Rosa MRD, Albuquerque SSL, Júnior AAV, Coelho AEL. Comportamento dos Cirurgiões-Dentistas em Relação à Utilização do Equipamento de Proteção Individual(EPI) no Controle de Infecções. Rev. Bras. Ciênc. Saúde 2001; 5(2):125-130.

3. Machado GL, Kather JM. Estudo do controle da infecção cruzada pelos cirurgiões-dentistas de Taubaté. Rev. Biociênc. Jan-Jun 2002; 8(1):37-44.

4. Centers for Disease Control and Prevention. Guidelines for Infection Control in Dental Health-Care Settings 2003. MMWR. Dec 2003; 52(RR-17):1-66.

5. Brasil. Ministério da Saúde. Agência Nacional de Vigilância Sanitária. Serviços Odontológicos: Prevenção e Controle de Riscos. 2a ed. Brasília: ANVISA; 2006. 152 pp.

6. Medeiros UV, Souza MIC, Bastos LF. Odontologia do trabalho: riscos ocupacionais do cirurgião-dentista. Rev Bras Odontol. Jul-Ago 2003; 60(4):277-80.

7. Block SS. Disinfection, Sterilization, and Preservation. $5^{a}$ ed. Philadelphia: Lippincott Williams \& Wilkins; 2000. 1504 pp.

8. Centers for Disease Control and Prevention. Guideline for Hand Hygiene in Health-Care Settings: Recommendations of the Healthcare Infection Control Practices Advisory Committee and the HICPAC/SHEA/APIC/IDSA Hand Hygiene Task Force. MMWR. Oct 2002; 51(RR-16):1-45

9. Naressi SCM, Akama CM, Silva LMP, Siviero M. Análise das formas de esterilização e do meio de controle empregados pelos cirurgiões-dentistas de São José dos Campos - SP. Rev Odontol UNESP. Out-Dez 2004; 33(4):169-74.

10. Agência Nacional de Vigilância Sanitária - ANVISA. Biossegurança. Rev Saúde Pública. Dec 2005; 39(6):989-91.

11. Zenkner CL. Infecção cruzada em odontologia: Riscos e diretrizes. Revista de Endodontia Pesquisa e Ensino On Line. Jan-Jun 2006; 2(3).
12. Cavalcante NJF, Monteiro ALC, Barbieri DD. Biossegurança. Atualidades em DST/AIDS. 2a ed. São Paulo: Programa Estadual de DST/AIDS da Secretaria do Estado da Saúde de São Paulo; 2003. 80 pp.

13. Brasil. Ministério da Saúde. Secretaria de Políticas de Saúde. Coordenação Nacional de DST e AIDS. Controle de infecções e a prática odontológica em tempos de AIDS: manual de condutas - Brasília: Ministério da Saúde; 2000. 118 pp.

14. Guimarães JJ. Biossegurança e controle de infecção cruzada em consultórios odontológicos. $1^{\text {a }}$ ed. São Paulo: Santos; 2001. 536 pp.

15. Lockhart PB, Loven B, Brennan MT, Fox PC. The evidence base for the efficacy of antibiotic prophylaxis in dental practice.J Am Dent Assoc. Apr 2007; 138(4):458-74.

16. Russo E, Russo EMA. Controle de infecção e normas de biossegurança: uma necessidade e uma obrigação. Rev Odontol UNICID. Jan-Abr 2001; 13(1):63-72.

17. Bulgarelli AF, Torquato TM, Costa LSS, Ferreira ZA. Avaliação das medidas de biossegurança no controle de infecção cruzada durante tratamento periodontal básico. Rev Bras Odontol. Mai-Jun 2001; 58(3):188-90.

18. Graziano KU, Manrinque EI, Fernandes AT, et al. Controle de infecção na prática odontológica. São Paulo: Associação Paulista de Estudos e Controle de Infecção Hospitalar (APECIH); 2000. 87 pp.

19. São Paulo (Estado). Secretaria de Estado da Saúde. Resolução SS-374, de 15/12/1995. Altera a Norma Técnica sobre a organização do Centro de Material e Noções de Esterilização. Diário Oficial do Estado, São Paulo, 16/12/1995.

20. São Paulo (Estado). Secretaria de Estado da Saúde. Resolução SS- 27, de 28/02/2007. Aprova Norma Técnica que institui medidas de controle sobre o uso do Glutaraldeído nos Estabelecimentos Assistenciais de Saúde. Diário Oficial do Estado, São Paulo, no 73 de 18/04/2007.

21. Silva ASF, Ribeiro MC, Risso M. Biossegurança em Odontologia e Ambientes de Saúde. 2o ed. São Paulo: Ícone; 2009. $262 \mathrm{pp}$.

22. Patiño-Marín N, Loyoa-Rodriguez JP, Tovar Reyes LF. Uso y verificación côn indicadores biológicos em esterilizadores de cirujanos dentistas de San Luis Potosí, México. Salud Publica Mex. Sep-Oct 2001; 43(5):455-8.

23. Monarca S, Grottolo M, Renzi D et al. Evaluation of environmental bacterial contamination and procedures to control cross infection in a sample of Italian dental surgeries. Occup Environ Med. Nov 2000; 57(11):721-6.

24. Corrêa EG, Castilho ARF, Pereira CV. Indicadores químicos e biológicos da eficácia de esterilização por autoclave ou estufa. Rev odonto ciênc. Abr-Jun 2009; 24(2):156-160.

25. Sindicato dos Odontologistas do Estado de São Paulo. Manual do Cirurgião-Dentista. São Paulo: SOESP; 2009. $22 \mathrm{pp}$.

26. Marino CGG, El-Far F, Wey SB, Medeiros EAS. Cut and puncture accidents involving health care workers exposed to biological materials. Braz J Infect Dis. Out 2001; 5(5):235-242.

27. Gordon Bl, Burke FJT, Bagg J et al. Systematic review of adherence to infection control guidelines in dentistry. J Dent. Nov 2001; 29(8):509-16.

28. Reis RK, Gir E, Canini SRMS. Accidents with biological material among undergraduate nursing students in a public Brazilian university. Braz J Infect Dis. Fev 2004; 8(1):18-24. 
29. Veronesi L, Bonanini M, Dall'Aglio P et al. Health hazard evaluation in private dental practices: a survey in a province of northen Italy. Acta Biomed. Apr 2004; 75(1):50-5.

30. Khader Y, Burgan S, Amarin Z. Self-reported needle-stick injuries among dentists in north Jordan. East Mediterr Health J. Jan-Feb 2009; 15(1):185-9.
31. Silva JA, Paula VS, Almeida AJ et al. Investigação de Acidentes Biológicos entre Profissionais de Saúde. Esc. Anna Nery Rev. Enferm. jul-set 2009; 13(3):508-16.

32. Lima AA, Azevedo AC, Fonseca AGL et al. Acidentes Ocupacionais: Conhecimento, Atitudes e Experiências de Estudantes de Odontologia da Universidade Federal da Paraíba. Pesq Bras Odontoped Clin Integr. set-dez 2008; $8(3): 327-332$. 